\title{
Advancing Access to Justice for the Poor and Vulnerable through Legal Clinics in Ethiopia:
}

Constraints and Opportunities

\author{
Mizanie Abate, Alebachew Birhanu, ${ }^{* *}$ and Mihret Alemayehu
}

\begin{abstract}
The right of access to justice, inter alia, enjoins states to provide legal aid services and employ legal literacy programs. It also ensures access to legal and justice institutions or legal remedies to the indigent and the vulnerable. Although the right of access to justice is guaranteed in Ethiopian laws, it continues to be unavailable to most citizens particularly to the indigent and the vulnerable because the different mechanisms (designed to ensure access to justice to these groups) have not been accorded sufficient legal recognition and are poorly implemented. We argue that law school legal clinics could be among the viable pursuits in addressing the gap. However, this study reveals that legal clinics per se are non-existent. In many law schools, the establishment of legal clinics has been hindered by lack of expertise, commitment of law schools to run clinical programs and financial problems. Law schools can meaningfully contribute to fill the gaps of access to justice in Ethiopia, if their legal aid centers are consolidated and used as legal clinics, and if clinical legal education is provided in accordance with the curricula designed in 2006 and 2013.
\end{abstract}

\section{Key terms}

Legal clinics, legal aid, access to justice, law schools, Ethiopia

DOI http://dx.doi.org/10.4314/mlr.v11i1.1

This article is licensed under a Creative Commons Attribution-NonCommercial-

NoDerivs (CC BY-NC-ND)

* Mizanie Abate: LL.B (Addis Ababa University), LL.M (University of Pretoria), PhD (the University of Alabama), Assistant Professor at Addis Ababa University, School of Law. Email: <mizanie.abate@aau.edu.et>

Alebachew Birhanu: LL.B (Addis Ababa University), LL.M and M.Phil (University of Oslo), Assistant Professor at Bahir Dar University, School of Law.

Email: <Alebe2007@gmail.com>

Mihret Alemayehu: LL.B (Addis Ababa University), LL.M and M.Phil (University of Oslo), Lecturer at Bahir Dar University, School of Law. Email: <mhret06@yahoo.com> 


\section{Introduction}

Regardless of the normative imperatives that necessitate its emergence, the term access to justice has remained a subject of ongoing debate since its inception. Different commentators have described the term differently. There has been little agreement about the meaning of access to justice, and the term "has over time become politically loaded and thus necessarily problematic". ${ }^{1}$ This article does not deal with various conceptions of access to justice. It rather focuses on the current concern toward promoting and achieving the social inclusion of the poor and vulnerable in accessing justice. In view of this, the term access to justice refers to the ability of individuals or groups to institute cases for alleged infringement of rights before judicial and quasi-judicial bodies and the possibility for the adjudicating body to deliver judgment on the "claim in a fair and impartial fashion on the basis of the evidence and according to the applicable rules of law".2

The right of access to justice is guaranteed in a number of global and regional human rights instruments which Ethiopia has adopted. ${ }^{3}$ In addition to the human rights instruments, the right of access to justice is also expressly recognized in the Federal Democratic Republic of Ethiopia (FDRE) Constitution. ${ }^{4}$

Vulnerable members of the society, such as children, women, people living with HIV/AIDS and persons with disabilities face difficulties to seek remedies for the infringement of their rights owing to lack of money, ignorance of the law and lack of awareness of litigation procedures. Cognizant of this fact, various jurisdictions, including Ethiopia, have designed a myriad of strategies to ensure access to justice. These, inter alia, include pro bono service by practicing lawyers, legal aid services, legal literacy and public interest litigation by law school legal aid centers and civil society organizations. As a matter of reality, however, access

The authors would like to thank Bahir Dar University for covering the fund needed for data collection for this research and Mekelle University for giving us the opportunity to present the earlier version of this work at a National Workshop on the Role of Higher Education-based Legal Advocacy \& Research Centers in Enhancing Access to Justice and Effective Legal Education, organized by Mekelle University School of Law (Legal Aid Center and Human Rights Center), Mekelle, Ethiopia (13 June 2015).

${ }^{1}$ Estelle Hurter (2011), 'Access to Justice: to Dream the Impossible Dream?' 44(3) CILSA, p. 413.

2 Samuel P. Baumgartner (2011), 'Does Access to Justice Improve Countries' Compliance with Human Rights Norms?: An Empirical Study,' 44 Cornell International Law Journal, p. 457. For similar definition, see also M. Elvira Méndez Pinedo (2011), 'Access to Justice as Hope in the Dark in Search for a New Concept in European Law', 1(19) International Journal of Humanities and Social Science, p. 9.

${ }^{3}$ See, for example, article 8 of the Universal Declaration of Human Rights, articles 2, 3(a), 7(1(a)(c) and (d), 9(4), $14(1), 14(3)(c)$ of the ICCPR.

${ }^{4}$ The Constitution of the Federal Democratic Republic of Ethiopia, 1995, Federal Negarit Gazzeta, Proc. No. 1/1995, No.1, $1^{\text {st }}$ year 1995, arts. 37, 19, 20, 21 and 25. 
to justice continues to be unavailable for most Ethiopians particularly to the indigent, women, children, persons with disability and persons living with HIV/AIDS. ${ }^{5}$ This is attributable to gaps in the different mechanisms that are designed to ensure access to justice to the indigent and vulnerable groups because sufficient legal recognition has not been given to these schemes, and are poorly implemented.

Given the legal and practical challenges that hinder the utilization of the various mechanisms of ensuring access to justice to the marginalized and the poor, law school legal clinics could be attractive and viable. Clinical Legal Education (CLE), which offers the framework for the operation of legal aid clinics, is recognized in the 2006 LLB Legal Curriculum. ${ }^{6}$

The main objective of this study is to critically assess the status, operation and effectiveness or otherwise of legal clinics in Ethiopian law schools toward realizing access to justice for the poor and vulnerable groups. To achieve this research objective, qualitative research methodology has been employed, and pertinent policies, laws and other documents have been analyzed. Empirical data was collected through in-depth interview, focus-group discussions and observations. The researchers have administered a combination of structured, semi-structured and to some extent unstructured interview while gathering data from research participants.

Law schools from ten universities, namely: Addis Ababa University, Hawassa University, Haramaya University, Jimma University, Dire Dawa University, Adama Science and Technology University, Bahir Dar University, University of Gondar, Debre Birhan University, and Mekelle University were taken as samples. In the selection of these schools, time of establishment, actual service delivery and experience of service rendition have been taken into account. From each law school, fifth $\left(5^{\text {th) }}\right.$ year regular law students, one clinical course instructor, one legal aid coordinator and the dean/department head were selected as research participants. The field data from the above universities were collected in 2015, and they have been updated.

The first section of this article presents the human rights dimension of access to justice. With the overall purpose of identifying strengths and limitations, Section Two discusses the mechanisms of realizing access to justice to the vulnerable. After briefly analyzing the Ethiopian Legal Education and Reform Document that recognizes CLE in Section Three, the role of legal clinics in enhancing access to

\footnotetext{
${ }^{5}$ The World Bank, Ethiopia Legal and Judicial Sector Assessment, 1818 H Street NW, Washington DC: USA, 2004, p. 29, Available at www.worldbank.org (accessed on 20 January 2012).

${ }^{6}$ Mizanie Abate Tadesse (2009), 'Clinical Legal Education in Ethiopia: Challenges and Prospects’, 2 Ethiopian Journal of Legal Education, p. 42.
} 
justice in Ethiopia is examined in the fourth section. Section Five examines the status and operation of legal clinics in Ethiopia, followed by a discussion on the challenges and opportunities in their implementation in the last section. Finally, conclusions and the way forward are drawn from the analysis in the sections.

\section{Access to Justice as a Human Right}

\subsection{The recognition of the right under human rights instruments}

As mentioned above, access to justice is not only a right in itself; it is also an "enabling and empowering right" as it allows right holders to enforce their rights and obtain redress. ${ }^{7}$ However, the term "access to justice" has not been explicitly used as a legal terminology in human rights instruments. Instead, various terms were used in these documents. Article 8 of the UDHR states that "everyone has the right to an effective remedy by the competent national tribunals for acts violating the fundamental rights ...." The ICCPR in a number of provisions refers to an "effective remedy" for violations of all the rights in the Covenant (article 2(3a)), and guarantees the right to "take proceedings before a court" (article 9(4)), the right to a "fair and public hearing" (article 14(1)), and the right to be tried without undue delay (article 14(3) (c)).

A similar approach is followed by the European Convention on Human Rights (ECHR) -as it only refers to the right to fair trial and the right to remedy $-{ }^{8}$ and the African Charter on Human and Peoples Rights (ACHPR). Article 7(1) of ACHPR provides for the "the right to have his cause heard" which, among others, comprises "the right to an appeal to competent national organs against acts violating his fundamental rights (article 7(1)(a)), "the right to defense, including the right to be defended by counsel of his choice'”(article 7(1)(c)), and "the right to be tried within a reasonable time by an impartial court or tribunal' '(Article 7(1)(d)).

The African Commission on Human and Peoples' Rights has developed Principles and Guidelines on the Right to a Fair Trial and Legal Assistance in Africa. The Principles and Guidelines elaborate the requirements for fair and public hearing, independent and impartial tribunal, competence of the judiciary, effective remedy, locus standi, access to lawyers and legal services, legal aid and legal assistance, and independence of lawyers. ${ }^{9}$ Although these are in

\footnotetext{
${ }^{7}$ See also European Union Agency for Fundamental Rights, Access to Justice in Europe: An Overview of Challenges and Opportunities, (Luxembourg, Publications Office of the European Union, 2011), p.3.

${ }^{8}$ ECHR, arts. 6 \&13.

${ }^{9}$ African Commission on Human and Peoples Rights (2003), Principles and Guidelines on the Right to a Fair Trial and Legal Assistance in Africa (2003). Available at: $<$ http://www.achpr.org/instruments/principles-guidelines-right-fair-trial/>
} 
essence the basic components of the right of access to justice, the Commission fails to employ the term access to justice as a legal terminology.

The term 'access to justice' began to be used as a legal terminology in the human rights discourse starting from the 1970s and 1980s following the works of Mauro Capelletti. ${ }^{10}$ Few instruments that came into effect after this time expressly employed the term. For example, the 1998 Aarhus Convention on Access to Information, Public Participation in Decision-Making and Access to Justice in Environmental Matters defines 'access to justice' as "access to a review procedure before a court of law or another independent and impartial body established by law". ${ }^{11}$ Another instrument which explicitly mentions "access to justice" is the 2006 UN Convention on the Rights of Persons with Disabilities. ${ }^{12}$

In the European regional system, a specific reference to access to justice was introduced by the Treaty of Lisbon: the Treaty on the Functioning of the European Union (TFEU). Article 67(4) of this treaty stipulates that "the Union shall facilitate access to justice, in particular through the principle of mutual recognition of judicial and extrajudicial decisions in civil matters." ${ }^{, 13}$ Moreover, the European Charter of Fundamental Rights (CFR) -in Article 47- provides for the "right to an effective remedy and to a fair trial". ${ }^{14}$ The third paragraph of Article 47 specifically refers to 'access to justice' in the context of legal aid while also trying to summarize all the particular rights enshrined in the concept of 'access to justice.'

The FDRE Constitution uses the term 'access to justice'. Article 37 titled 'Right of Access to Justice' reads: "[e]veryone has the right to bring a justiciable matter to, and to obtain a decision or judgment by, a court of law or any other competent body with judicial power". ${ }^{15}$ Moreover, the various components of the right are found in different sections of the Constitution as are in international human rights instruments. ${ }^{16}$

\subsection{The components of the right to access to justice}

Many human rights instruments deal with the various aspects of the notion of access to justice while a few of them, -notably, the CFR and the Principles and

\footnotetext{
${ }^{10}$ European Union Agency for Fundamental Rights, supra note 7.

${ }^{11}$ The Aarhus Convention on Access to Information, Public Participation in DecisionMaking and Access to Justice in Environmental (1998), art.9 (1).

12 The UN Convention on the Rights of Persons with Disabilities (2006), Art. 13..

${ }^{13}$ Charter of Fundamental Rights of the European Union (2000/C 364/01) (Herein After CFR), Article 6.

${ }^{14}$ Id., art.47.

${ }^{15}$ FDRE Constitution, art.37 (1).

${ }^{16}$ Id., arts. 19, 20, 21 and 25.
} 
Guidelines of the Right to Fair Trial and Legal Assistance- stipulate the elements of access to justice elaborately. ${ }^{17}$ In many legal systems, the notion of access to justice is built from such explicit and implicit recognition of rights like access to courts; trial by competent, independent and impartial tribunals; fair and public proceedings, effective redress, and legal assistance and legal aid.

Effective access to courts and tribunals is very essential in order to enforce one's rights. For access to be effective, physical and non-physical barriers should be removed, or at least be kept at a minimum. ${ }^{18}$ Physical proximity of courts and tribunals should be guaranteed and court fees should be kept at a minimum not to bar individuals from petitioning courts to obtain redress. ${ }^{19}$ First instance and appellate procedures by competent, independent and impartial courts and tribunals should be equally accessible for all sections of the society including the poor, the disadvantaged, the marginalized, women, children, the disabled, and others. ${ }^{20}$ Court personnel should be disciplined and trained, ${ }^{21}$ and be independent and impartial in the exercise of their function. ${ }^{22}$ Recruitment, promotion and removal of judges should be made by a neutral body, and tenure of judges should normally be for life (until retirement). ${ }^{23}$

For justice to be served on an equal basis, procedural equality and fairness should be ensured and proceedings be conducted in public which serves as a guarantee for its fairness. Moreover, disputes should be resolved expeditiously as "justice delayed is justice denied". ${ }^{4}$

For access to justice to be meaningful, petitioners should be able to obtain adequate redress or effective remedy. ${ }^{25}$ Adequate redress is commensurate with the harm suffered as a result of the violation of human rights or other legal rights. Redress may include: restitution, compensation, rehabilitation, satisfaction, and guarantees of non-repetition. ${ }^{26}$

An important element of access to justice which is more pertinent to this research is the right to have legal assistance and legal aid. It comprises the right to have a counsel (the right to be advised), the right to be defended and

\footnotetext{
${ }^{17}$ See Principles and Guidelines on the Right to a Fair Trial and Legal Assistance in Africa (2003).

${ }^{18}$ HRC GC 32, para. 9 \& 11.

${ }^{19}$ Id., para. 11.

${ }^{20}$ ICCPR, art.14 (1).

${ }^{21}$ HRC GC 32, para. 18-20.

${ }^{22}$ Ibid.

${ }^{23}$ Ibid.

${ }^{24}$ ICCPR, art.14 (3) (c). See also GC 32.

${ }^{25}$ Id., art.2 (3); UDHR, art.8; CAT, art. 14(1); CERD art. 6; and CEDAW, art.2.

${ }^{26}$ Basic Principles and Guideline on the Right to a Remedy and Reparation for Victims of Gross Violations of International Human Rights Law, 2005.
} 
represented, and the right to legal aid where the person has no sufficient funds for private representation. ${ }^{27}$

Although legal assistance may only be provided by lawyers, some limited services may be provided by paralegals, lawyers-in-training, law students, or advocates when lawyers are in short supply. ${ }^{28}$ With proper supervision and training, such assistance can be vital for people whose needs might be unmet otherwise. ${ }^{29}$ Ensuring the services to be reliable will of course be a challenge in such cases.

In addition to recognizing the rights, human rights instruments impose obligations on state parties. For instance, the ICCPR obliges states: "to respect and ensure to all individuals within its territory and subject to its jurisdiction the rights recognized in the Covenant without distinction of any kind", and "to take necessary steps to give effect to the rights, to ensure effective remedy in case of violation, and enforce such remedies when granted.” ${ }^{30}$ Generally, states have the obligation to respect, protect and promote human rights including the right of access to justice. $^{31}$

As a State party to many international and regional human rights instruments, Ethiopia has the obligation to realize the right of access to justice and has, accordingly, put in place various mechanisms thereof. The mechanisms of access to justice and their strengths and limitations are briefly discussed in the following section.

\section{Strengths and Limitations in the Models of Legal Aid Services in Ethiopia}

Legal aid services involve the concerted efforts of states and non-States actors. In this regard, Ethiopian law has introduced different models of legal aid services, which are in operation. These include legal aid services delivered by the government, the legal profession and NGOs. The strengths and limitations of the different legal aid service models are highlighted below.

${ }^{27}$ See ICCPR, art. 14(3)(d); and ECHR, art. (6) (3) (c). The divergence in national laws regarding this right is on accessing a lawyer within 24 hour of arrest; while some prohibit this, other do allow.

${ }^{28}$ Legal Defense and Legal Aid, UN Criminal Justice Toolkit (New York, 2006), p.6.

${ }^{29}$ Id., p. 9.

${ }^{30}$ ICCPR, art. 2. See also the Declaration on Human Rights Defenders, Art. 2(1).

${ }^{31}$ Asbjorn Eide, Caterina Krause and Allan Rosas (2001), Economic, Social and Cultural Rights: A Textbook (Martinus Nijhoff Publishers,) p.23. See also HRC General Comment No. 31 (2004) para. 8; Declaration on Human Rights Defenders art. 2(1); and ICCPR art. 2. 


\subsection{Government-delivered legal aid services}

The provision of legal aid services in criminal matters is the primary responsibility of states. Accordingly, the Ethiopian government provides legal aid services through two institutions: the Public Defender's Office (PDO), and other mandated government institutions including the Ministry of Justice (now the Attorney General)/regional justice Bureaus. The PDO was established in 1995 under the supervision of the Ethiopian Federal Supreme Court. The staff of the PDO has grown over the years although it originally consisted of five attorneys, only one of whom was an experienced trial attorney. ${ }^{32}$ The PDO provides legal aid services to indigents charged with genocide, juvenile delinquents, corruption, treason, and other criminal allegations. ${ }^{33}$

Indigent criminal defendants have a constitutional right to legal representation at the expense of the government where the interest of justice so requires. ${ }^{34} \mathrm{In}$ reality, however, the constitutional guarantee of legal representation -to the indigent by public defenders- has not been fulfilled because PDO operates under severe constraints. ${ }^{35}$ The prime constraint to the provision of legal aid services is the absence of public defenders office in courts at all levels. There are only two public defender's offices in Addis Ababa at the federal level while many regional courts are yet to incorporate public defender offices. ${ }^{36}$ Thus, the coverage of aid service by public defenders is inadequate. In fact, the existing PDO has suffered from lack of resources and understaffing. ${ }^{37}$ The situation is aggravated owing to lack of public awareness. As a result, PDO provides

32 Julie Mayfield (1995), 'The Prosecution of War Criminals and Respect for Human Rights: Ethiopia’s Balance Act', Emory International Law Review, Vol. 9, P.584.

${ }^{33}$ The World Bank, supra note 5, p. 30.

In its performance report, the Supreme Court indicated that the PDO has represented 7,650 beneficiaries before courts in the 2015/16 budget year. See Federal Supreme Court, 2008 E.C. Budget Year Performance Report:

$<$ http://www.fsc.gov.et/AnnualReports/Index1, (accessed on 7 August 2017).

${ }^{34}$ FDRE Constitution, art 20(5).

${ }^{35}$ UNODC, Access to Legal Aid in Criminal Justice Systems in Africa: Survey Report, 2011, P.9.

${ }^{36}$ World Bank, cited at note 4 above, p. 30. See also Abera Hailemariam Woldeyesus (2015), in Chapter 5, Public Defender's Services in Ethiopia: Assessment of Current Gaps and the Way Forward, E. N. Stebek (ed.), Ethiopian Lawyers Association and Ethiopian Young Lawyers Association, pp.34-39,

$<$ http://www.ethiopian-bar.org/index.php/publications/doc_view/67-public-defender-sservices-in-ethiopia>, (accessed on 7 August 2017). It is important to note that although regional public defender offices are not established, there are a few public defenders at regional supreme courts.

37 Abera Hailemariam, Ethiopian Lawyers Association and Ethiopian Young Lawyers Association, Id., p. 66. 
minimal legal aid service in many criminal cases. ${ }^{38}$ One can generally say that legal representation to indigent criminal defendants by public defenders is very limited.

Moreover, legal aid services are directly provided -at least at federal levelthrough government institutions such as the former Ministry of Justice (MoJ). ${ }^{39}$ The MoJ, now the Attorney General, is mandated, inter alia, "to represent citizens, in particular women and children, who are unable to institute and pursue their civil suits before the federal courts". ${ }^{40}$ This authorization allows the Attorney General to render legal aid services to women and children in civil matters. Accordingly, the Attorney General provides direct free legal aid service to women and children through legal officers assigned at all the ten sub-city prosecution branch offices of the Justice Bureaus located in Addis Ababa as well as in Dire Dawa. ${ }^{41}$

Moreover, the government has engaged in providing legal aid services to children through the Children's Legal Protection Center (CLPC) created under the auspices of the Child Justice Project Office of the Ethiopian Federal Supreme Court. ${ }^{42}$ The coverage of both schemes (the Attorney General and CLPC) is very limited in terms of geographical area and type of clients to ensure the realization of access to justice for poor and vulnerable.

\subsection{Legal profession-delivered legal aid services}

Another model for providing legal aid service is the utilization of legal profession which has historically been the main provider of legal aid services to the poor as required by the professional codes of conduct governing professional legal practice. ${ }^{43}$ An effective justice system requires the legal profession to provide services toward justice that are necessary at a standard equal to those provided by the State. ${ }^{44}$

${ }^{38}$ UNODC, Survey Report, supra note 35, p.9.

${ }^{39}$ Kokebe Wolde (ed.), Assessment of Legal Aid in Ethiopia: A Research Report and Proceedings of the National Workshop of Legal Aid Providers, Center for Human Rights, AAU, 2013, p.53.

${ }^{40}$ Definition of Powers and Duties of the Executive Organs of the Federal Democratic Republic of Ethiopia Proclamation, Proclamation No. 691/2010, 2010, art. 16(11).

${ }^{41}$ Kokebe, supra note 39, p. 58. Some regions justice bureaus like ANRS have followed similar approach.

${ }^{42}$ Id., The Children's Legal Protection Center began the provision of legal aid service in 2012 and targets children and their caregivers who either represent children or faced their own problems which affect the best interest of children.

${ }^{43}$ Kokebe, supra note 39, p.37.

${ }^{44}$ UNODC, Access to Legal Aid in Criminal Justice Systems in Africa: Handbook, 2011, p. 12. 
In Ethiopia, the provision of legal aid services by the legal profession can be either mandatory pro bono services or voluntary services of legal professional associations. The requirement to offer mandatory pro bono services is statutory. The Federal Court Advocate's License and Registration Proclamation imposes an obligation on practicing lawyers to render 50 hours of pro bono legal aid service to the poor annually. ${ }^{45}$ Some regional states have devised a different scheme regarding the extent of pro bono legal obligations of lawyers. For instance, the recent Tigray regional Courts Advocate's License and Registration Proclamation No. 262/2007 EC has introduced the obligation of at least one file representation per year instead of the 50 hours of pro bono legal services. This shift in approach makes sense given that 50 hours may not be enough in some cases.

In spite of the robust legal basis, studies show that there is no meaningful mandatory legal aid service in Ethiopia. ${ }^{46}$ In fact, the availability of mandatory pro bono service is seriously limited especially at the more rural district levels where lawyers are unavailable, and indigent criminal defendants are largely unaware of the existence of lawyers at the expense of the government. ${ }^{47}$ Moreover, the Ministry of Justice (currently the Attorney General) and Regional Justice Bureaus have failed to discharge their duty of supervising the implementation of the fifty hours pro bono obligation incumbent on lawyers. ${ }^{48}$ Accordingly, the duty of the practicing lawyers to provide pro bono legal service is hardly utilized in Ethiopia. ${ }^{49}$

The other sources of legal aid service are professional associations. The Ethiopian Lawyers Association has been working in the provision of legal aid

45 Federal Courts Advocates Licensing and Registration Proclamation No.199/2000, and Federal Courts Advocates' Code of Conduct Regulations No. 57/1999.

${ }^{46}$ Hussein A. Tura (2013), 'Indigent's Right to State Funded Legal Aid in Ethiopia', IHRL Review 2, p.138. See also Ghetnet Mitiku Woldegiorgis, Access to Justice and Legal Aid in Ethiopia, Available at: < http://www.abyssinialaw.com/blog-posts/item/1448-access-tojustice-and-legal-aid-in-ethiopia>, accessed on 21/11/2014, p.3.

47 World bank, cited at note 5 above, p.31. The problem was also identified by a study conducted by Abera Hailemariam Woldeyesus (2015), Needs Assessment Report on the State of Legal Aid Services: Assessments on Addis Ababa, Adama, Assosa, Bahir Dar, Hawassa, Jigjiga and Mekelle, E. N. Stebek, ed., the Ethiopian Lawyers Association. See Ethiopian Lawyers Association.

http://www.ethiopian-bar.org/index.php/publications/doc_view/66-need-assessementreport-on-legal-aid, (accessed on 7 August 2017).

${ }^{48}$ Abera Hailemariam, Ethiopian Lawyers Association, id., p. 2.

49 Ethiopian Bar Association, Enforcement of the Law on Pro Bono Responsibility of Federal Courts Advocates in Ethiopia, http://www.cba.org/sajea/en/main/events.aspx (accessed on 10 July 2011). 
services to the indigent members of the society in Addis Ababa. ${ }^{50}$ The Ethiopian Bar Association (EBA), and Alumni Association of Law Faculty of Addis Ababa University (AALF-AAU) have provided legal aid service in the premises of the Federal High Court Lideta Branch and Federal First Instance Court Arada Branch, and EBA's third legal aid center. ${ }^{51}$ The participation of these (and other) professional associations enables members to fulfil their professional obligations of providing 50 hours of annual pro bono legal services. However, the legal aid service that is being provided by these institutions is extremely limited both in its geographical coverage and the number of beneficiaries. ${ }^{52}$

\subsection{Legal aid services by law schools}

The law school legal aid centers are alternative avenues in the provision of legal aid services in Ethiopia. For example, Mekelle University School of Law Legal Aid Center (formerly known as Mekelle University Law Faculty Legal aid Center: MULF-LAC) began its operation by providing training to the regional social court judges and has been providing advocacy works to the vulnerable segments of the community in the region since 2014. ${ }^{53}$ Bahir Dar University Faculty of Law (now School of Law) followed the same path a year later. Currently, all law schools selected for this research are running legal aid centers in their respective towns by involving students, academic staff and employed lawyers. They provide legal aid services to the poor and vulnerable.

Although legal aid centers of law schools have carried out commendable tasks, many of them have faced challenges in the process. Legal aid centers of some law schools are not funded by their respective Universities. Consequently, they are compelled to look for external funding which has been unsustainable.

\subsection{Legal aid services delivered by NGOs}

The other option for the provision of legal aid services in Ethiopia is NGO voluntarism in the legal profession (public interest lawyers), and community capacity creation (paralegals). ${ }^{54}$ The Federal Courts Advocates Licensing and

${ }^{50}$ Kokebe, supra note 39, p.59. The Ethiopian Lawyers Association was created in 1967, and the Ethiopian Christian Lawyers' Association was established in 2008.

${ }^{51}$ Ghetnet Mitiku, supra note 46, p.3.

${ }^{52}$ Abera Hailemariam, Ethiopian Lawyers Association, supra note 47, p.46.

${ }^{53}$ Mekelle University School of Law Experience on Provision of Legal Aid presented at a Workshop on "Legal Aid and Access to Justice", organized by AAU Center for Human Rights Studies, April 23-24, 2015; and United Nations, Handbook on Improving Access to Legal Aid in Africa: Criminal Justice Handbook Series. New York. 2011, p. 31.

${ }^{54}$ Ghetnet Mitiku, The Role and Contributions of Ethiopian Civil Society Organizations in the Provision of Legal Aid Services, available at:

$<$ http://www.slideshare.net/gmgiorgis/role-contributions-of-ethiopian-cs-os-in-legal-aidenglish>, accessed 31 March, 2015. See also the APAP Paralegals Training Programme, Awareness, Vol.1, Issue 3, March 1996. Paralegal is a person who provides legal aid and 
Registration Proclamation requires Ethiopian NGOs or individuals to secure a special advocacy license if they intend to take part in actio popularis. Article 10 of the Proclamation provides that "any Ethiopian who defends the general interests and rights of society..." will be issued with a Federal Court Special Advocacy License on condition that certain requirements are met. ${ }^{55}$ In reality, no NGO has been able to secure such license owing to the reluctance of the licensing authority, the Ministry of Justice. ${ }^{56}$ Even though the Ministry of Justice was willing to issue such license for individual lawyers who meet the legal requirements, only few individuals applied and secured the license. ${ }^{57}$

At national and regional state levels, different NGOs have until recently rendered legal aid services ranging from legal advice to representation to specific social groups such as women and children. In this regard, the Ethiopian Women Lawyers Association (EWLA) provides legal advice, counselling and representation to victims of gender based violence and violence against women in criminal and civil cases in Addis Ababa, Adama, Dire Dawa, Hawassa, Gambella, Assosa and Bahir Dar. ${ }^{58}$ In collaboration with other partners, it has so far, provided legal aid services to about 120,000 beneficiaries and trained more than 70,000 women. ${ }^{59}$ Action of Professionals Association for the People (APAP) also used to render legal aid services at the federal and regional levels. ${ }^{60}$

related service to the members of his/her community without passing through the process of legal education offered by the formal education system. For example, in Ethiopia paralegal service providers include social court judges, family arbitrators, and local elders engaged in arbitration related activities.

${ }^{55}$ According to article 10 of the Proclamation, an Ethiopian may be eligible for this issuance of this type of license where he: has a degree in law from a legally recognized educational institution; knows the basic laws of Ethiopia; has a minimum of five years relevant experience; may not receive any kind of reward from a section of a society; whose character is suitable for shouldering such responsibility; and is not convicted and sentenced in an offense.

${ }^{56}$ The Ministry of Justice turned down the application of APAP, a local NGO composed of lawyers, for the issuance of a special advocacy license. See Sisay Alemahu (2008), 'The Justiciability of Human rights in the Federal Democratic Republic of Ethiopia,” 8(2) African Human Rights Law Journal, p.292.

${ }^{57}$ On the basis of the available data, only two staff members of APAP had secured the license. See Sisay, cited at note 56 above, P. 292.

${ }^{58}$ Ghetnet Mitiku, supra note 54. EWLA was created in 1995 to ensure the equal enjoyment of rights by women in Ethiopia. It has been working for the protection of the rights of women and overall advancement and empowerment of women. The provision of free legal aid service to women is one strategy through which EWLA seeks to achieve its objective.

${ }^{59}$ Interview with Zenaye Tadesse, Executive Director, EWLA, Interviewed on April 14, 2016.

${ }^{60}$ Ghetnet Mitiku, supra note 54. APAP provided legal aid services in Addis Ababa, Bahir Dar, Hawassa, Dire Dawa, Jimma, Harar, Adama, Assela, and Debre Berhan. Following 
According to the 2007 annual report of the organization, APAP gave the service to 7,226 indigents. ${ }^{61}$ However, the legal aid services provided by NGOs could not extend beyond major urban areas.

Even worse, the limited provision of legal aid services by NGOs was further restricted after the coming into effect of the Charities and Societies Proclamation (Proclamation No. 621/2009). This is because the Proclamation reserves the task of promotion and protection of human rights to Ethiopian Charities and Civil Societies (CSO) that are able to derive more than $90 \%$ of their budget from internal sources; ${ }^{62}$ and this includes protection of human rights through the provision of legal aid services. This stipulation automatically excluded NGOs, such as APAP and Ye Ethiopia Goji Limadawi Dirgitoch Aswogaji Mahiber (EGLDAM), from providing legal aid services ${ }^{63}$ merely because $90 \%$ of their budget could not be obtained from internal sources.

As a matter of fact, there are limited local human rights NGOs in Ethiopia that raise their fund from local source. The notable NGOs in this regard, the Ethiopian Women's Lawyers Association and the Human Rights Council, are now extremely weakened owing to the decline in foreign funding to the extent that they are staggering to continue conducting their basic activities. ${ }^{64}$ The Ethiopian Human Rights Commission was funded by the UNDP's Democratic Institution Program (DIP), and had provided limited financial support to free legal aid centers of NGOs and professional legal education institutions so that they could continue to provide legal aid services to vulnerable groups. ${ }^{65}$ This fund is no longer available.

the coming into force of the Charities and Societies Proclamation in 2009, APAP quitted altogether the provision of legal aid service.

${ }^{61}$ Ghenet Mitiku, The Role and Contributions of NGOs, supra note 54, p.3. See also Ghetnet Mitiku, Access to Justice and Legal Aid in Ethiopia, supra note 46, p.4.

62 See Charities and Societies Proclamation, 2009, Proclamation No. 621/2009, Federal Negarit Gazeta, year 15, no.25, arts. 2(2) and 14 (5).

${ }^{63}$ Mizanie A. Tadesse (2013), A Rights-Based Approach to HIV Prevention, Care, Support and Treatment: A Review of Its Implementation in Ethiopia, PhD Dissertation, University of Alabama (Published, Ann Arbor: Proquest LLC, USA, Publication Number: 3550089, 2013), p.300.

${ }^{64}$ Committee on the Elimination of Discrimination against Women, Concluding observations of the Committee on the Elimination of Discrimination against Women: Ethiopia, Forty-ninth session, July 11 - 29, 2011, para. 29. See also Amnesty International, Ethiopia: Briefing to the UN Committee on Elimination of Discrimination Against Women, 2011.

${ }^{65}$ Ghetnet Mitiku, The Role and Contribution of NGOs, supra note 54. 


\section{Legal Education and Training Reform in Ethiopia: Recognizing CLE}

The beginning of modern legal education and training in Ethiopia can be traced back to the establishment of the Law Faculty of Addis Ababa University (AAU) in 1963 which was known as Haile Selassie I University (initially called the University College of Addis Ababa from 1950 to 1962). Pursuits of expanding access to high-level legal education and training is underway since the 1990s. According to data obtained from the Consortium of Ethiopian Law Schools, legal education is currently offered in more than 29 public universities. ${ }^{66}$

Although the issue of access to legal education was primarily a concern, the government realized that the quality of legal education both at Faculty of Law of Addis Ababa University and the newly established law schools was not up the required level. The government realized that the law schools were not in a position to produce competent legal professionals who will contribute to the enhancement of rule of law, democracy and socio-economic development. ${ }^{67}$ As a result, the government, in 2002, launched a study on the legal education and training reform as integral part of the National Comprehensive Justice Reform Program under the auspices of the then Ministry of Capacity Building.

The findings of the study conducted on legal education and training reform were incorporated in the 2006 Legal Education and Training Reform Document. The June 2006 Reform Document (which was approved in August 2006) at the conference of all law schools) indentified problems related to delivery, curriculum, leadership and research and publications, and it suggested solutions. Specific curriculum related problems identified include: absence of courses consciously designed to emphasize the centrality of good governance, democratization, economic development and social justice and other constitutional values; lack of sufficient number of skill-oriented courses; and lack of adequate number of courses that shape the ethical expectations and responsibilities of a law graduate. ${ }^{68}$

To alleviate curriculum-related problems, the reform document incorporates a new LL.B curriculum which was implemented as of September 2006 by the

${ }^{66}$ Interview with Seid Mohammed, Policy Analyst and Legal Eudcation Coordinator at Education Strategy Center, Interviewed on August 7, 2017.

${ }^{67}$ Legal Education and Training Reform Document (2006), p.7.

${ }^{68}$ Id., p.14. In terms of skill-oriented courses, there were attempts to include them in the old curricula of some law school although the way they were delivered was largely similar to other theoretical courses. For instance, the 2001/02 curriculum of School of Law, Mekelle University incorporated the following courses: Computer Skills for Lawyers, Legal Writing \& Research Methods for Lawyers, Practical Attachment (3 months), Lawyering Skills, Court Management, Case Management, Legislative Drafting, Legal Service (in two semesters) and Advanced Judicial Skills. 
then existing law schools. The 2006 LL.B Curriculum is a five-year program with a minimum of 154 credit hours of coursework and 20 credit hours of externship and exit exam. The curriculum introduced a number of new courses that are instrumental to rectify past problems. The newly introduced courses include clinical courses, externship and exit exam. The 2006 LL.B curriculum is currently replaced by the 2013 National Modularized Curriculum of the LL.B Program. As regards clinical courses, the new curriculum incorporates them without making any meaningful change both in terms of weight and status.

\section{The Role of Legal Clinics in Promoting Access to Justice}

Clinical Legal Education can be defined as "a program that teaches through direct experience of lawyering under the supervision of practicing attorneys/ teachers, characteristically in work that advances social justice or the public interest" ${ }^{69}$ For a teaching approach to be taken as CLE, aiming at instilling skill to law students is not adequate, because it should combine community service with practical student learning. ${ }^{70}$ The mere participation of law students in the provision of services in legal aid centers of law schools cannot be regarded as clinical education. This is because legal aid centers do not require students to register for the services a course. Nor are they assessed based on their performance in order to earn academic grades for their activities. Likewise, a legal education model which exclusively relies on simulation is not CLE as it does not allow the involvement of students "with real clients in an environment supervised and controlled directly by the law school.,"71

As long as clinical programs are incorporated in law curriculum with a broader mission of exposing law students to experiential learning and promoting social justices, there is no single way for their operation. CLE may follow diverse approaches depending on the curriculum of law schools, legal setting of jurisdictions in which it operates, types of social justice issues it seeks to address and resources available in law schools. ${ }^{72}$

CLE as a teaching methodology was originally introduced in a few law schools of the United States at the beginning of the twentieth century and was later expanded to all US law schools and transplanted by law schools of other

${ }^{69}$ Clinical Legal Education Association Handbook for New Clinical Teachers, April 2007, p.10.

70 Jeff Giddings (2013), Promoting Justice through Clinical Legal Education, Justice Press, , p. 4.

${ }^{71}$ Richard Lewis, Clinical Legal Education Revisited, Cardiff University, Wales, UK, p. 6. Available at: <https://core.ac.uk/download/pdf/8816908.pdf >

${ }^{72}$ Frank S. Bloch (2008), Access to Justice and the Global Clinical Movement, Wash. U. J. L. \& Pol'y, Vol. 28, p. 118. 
countries. $^{73}$ Initially, there were a few law schools in the US that had clinical legal education programs until the 1960s mainly because "law schools of this era were terribly underfunded and clinical legal education courses with intensive faculty supervision were not as economical as large classes employing the casebook Socratic Method". ${ }^{4}$ Availing themselves of initial funding from the Ford Foundation and driven by the need to promote social justice, the majority the US law schools introduced CLE in the late 1960s and early 1970s. ${ }^{75}$ Nowadays, CLE is implemented in all US law schools and other law schools in Canada, Great Britain, Australia, Latin America, Europe, China, India Israel, and Africa. ${ }^{76}$

The main reason for the consolidation and expansion of clinical legal education is the need to promote social justice in general and access to justice to the poor and vulnerable members of communities in particular. ${ }^{77}$ Although it is a globally recognized principle that "any country's system of justice must be accessible to all of its citizens," the situation on the ground tells us that lower income and other disfavoured groups of citizens "are unable to benefit from relief that might be available through their local legal systems." 78

Legal clinics played and continue to play a significant role towards meeting the access to justice needs of these members of the community. They do this in three ways. Firstly, lack of money is the main obstacle that prevents people from accessing justice in some countries. When access to justice is hindered for

${ }^{73}$ New York State Judicial Institute Partners in Justice: A Colloquium on Developing Collaborations Among Courts, Law School Clinical Programs and the Practicing Bar Introduction to Clinical Legal Education May 9, 2005, p. 1.

${ }^{74}$ Id., p. 5.

75 Stephen Wizner (2002), 'The Law School Clinic: Legal Education in the Interests of Justice', Fordham Law Review, Vol. 70, pp. 1933-34.

${ }^{76}$ Ibid. See also T.O. Ojienda and M. Oduor (2002), 'Reflections on the Implementation of Clinical Legal Education in Moi University, Kenya', International Journal of Clinical Legal Education, Vol. 2, 52.

${ }^{77}$ T.O. Ojienda and M. Oduor, supra note 76; and See also New York State Judicial Institute Partners in Justice, cited above at note 73, p.8. There is a debate, particularly in the US on the issue of whether the goal of law school clinic should be 'skill acquisitions' or 'social justice' On one side of the debate stand the proponents of the skills acquisition. They believe that most important goal of clinical education is to encourage law students to develop the skills and values necessary to become competent, ethical, reflective practitioners. On other side of the debate stand the proponents of social justice. Under this view, a primary purpose of law school clinics is to provide a practical vision of law as an instrument of social justice, such as rendering free legal aid to the indigent. This article doesn't attempt to make a hierarchy among the different goals of clinical legal education. It takes these goals equally important. See M J Rose (2007), “A 'Systems' approach to Clinical Legal Education”, 13 Clinical Law Review 780.

${ }^{78}$ Frank S. Bloch, supra note 72, p. 118. 
lack of money, provision of legal aid to the indigent is an approach countries have adopted to address the problem. The legal aid to be provided may extend from provision of legal advice to representation before judicial and quasi judicial bodies. Legal clinics play important role in the provision of legal aid in civil and criminal matters. ${ }^{79}$

Secondly, in many developing countries, "justice is inaccessible to a large number of people because they are unaware of laws and legal institutions, not to mention specific legal rights". ${ }^{80}$ To address this specific problem of access to justice, several countries have employed legal literacy programs and campaigns with a view to instilling basic legal awareness to citizens. These kinds of programs have been applied, for example, in India, Chile and South Africa partly through the involvement of legal clinics. ${ }^{81}$ Thirdly, in some cases, citizens do not access justice because the legal system itself restricts access to legal and justice institution or legal remedies. ${ }^{82}$ In this case, legal clinics can play an important role by challenging the status quo and pushing for legal reform.

As elsewhere, the purpose of inclusion of clinical courses in LL.B curriculum and establishment of legal clinics in Ethiopia is twofold. ${ }^{83}$ First, they are meant to be legal laboratories in which students can learn the practical application of the law. Second, they are intended to be avenues through which law school students contribute to the furtherance of access to justice to the poor and vulnerable members of the community. The Higher Education Proclamation states the provision of community service as one of the core missions of higher education institutions and their academic units. ${ }^{84}$ The establishment of legal clinics enables law schools to achieve this mission.

The introduction of clinical courses in the curriculum and setting the promotion of access to justice as one of their objectives is not incidental. This is done cognizant of the fact that access to justice continues to be a luxury for most Ethiopians particularly to the indigent, women, children, persons with disability and persons living with HIV/AIDS although it is a constitutional entitlement. ${ }^{85}$ As outlined under section two above, one of the reasons why access to justice has not been fully realized for the poor and the vulnerable in Ethiopia is because the

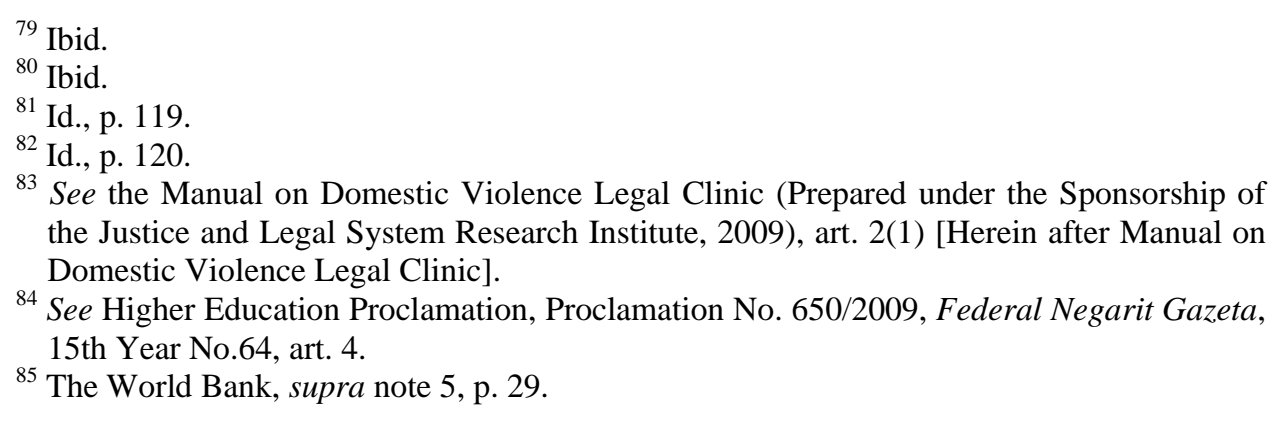


various avenues of ensuring access to justice are poorly implemented or have not been sufficiently and legally recognized.

Thus, given the legal and practical challenges that hinder the utilization of the various mechanisms of ensuring access to justice to the marginalized and the poor, law school legal clinics could be viable options in enhancing access to justice -to the poor and the vulnerable in Ethiopia.

\section{The Status of Legal Clinics in Ethiopia}

The existence and performance of legal clinics is mainly evaluated against curricular and legal clinic manual standards as well as the Model Code of Conduct Governing Students Involving in Legal Clinics and Externship Programme. The Manual on Domestic Violence Legal Clinic is used for the purpose of analyzing our data, because the six manuals on various legal clinics have similar content.

\subsection{The establishment of legal clinics}

Under the 2006 LL.B national curriculum, clinical courses are fifth year first semester elective courses. It is, however, a mandatory requirement that a student should take at least one clinical course. Reducing the number of clinical courses from six to four, the 2013 National Modularized Curriculum of the LL.B Program requires students to take at least one clinical course. As clinical courses are designed to enable students to learn from real experience through rendering various legal services to the community in need, their proper delivery and management presupposes the establishment of legal clinics with the necessary facilities.

As can be understood from the experience of other countries, the effective delivery of clinical courses requires the fulfilment of a number of facilities. Firstly, the legal clinic needs to have its own building. The building should consist of a client reception, waiting room and an interview room, all of which should afford security and preserve confidentiality. ${ }^{86}$ The building should also contain a focal point where students can be debriefed, discuss cases and receive notices. ${ }^{87}$ However, a separate building is not a rigid requirement because it may be shared with more than one clinic. Secondly, the legal clinic must have the necessary equipment. It should at least have: a dedicated telephone line or extension to ensure confidentiality, video equipments for recording purposes, computers, desks, chairs, student dresses, file drawers, transportation facilities,

\footnotetext{
${ }^{86}$ Clinical Legal Education Association, Handbook for New Clinical Teacher's (2007), http://cleaweb.org/documents/ CLE A New Clinicians Handbook 2007.pdf (last visit12 April 2009).

${ }^{87}$ Ibid.
} 
photocopy machine, and other stationery materials. ${ }^{88}$ Realizing that Ethiopian law schools may not have the finance and the preparation to furnish legal clinics at the initial phase of the implementation of clinical courses, the Justice and Legal Research System Research Institute (JLSRI) had purchased and distributed the necessary clinical equipments ${ }^{89}$ to all law schools in 2010.

In practice, however, no law school in Ethiopia has established a legal clinic per se let alone specialized legal clinics. Instead, various law schools have legal aid centers. Legal aid centers -established primarily with community service objective in mind and with an incidental aim of exposing students to the practice of law- cannot be taken as legal clinics although there are possibilities to use them as legal clinics with the necessary improvements. Legal aid centers, as mentioned above, lack important features of legal clinics, and they provide noncourse-credit earning legal services through selected volunteer students and lawyers employed for this purpose.

Short of legal clinics, an important good practice is using legal aid centers to host students of clinical courses. A case in point in this regard is Mekelle University School of Law in which the Legal Aid center and the Human Rights Center are used for conducting clinical courses. Both centers have been avenues of skill-oriented courses including clinical courses on top of service delivery by volunteer students. Another example is the experience of Addis Ababa University School of Law where students registered for clinical courses have been assigned at AAU Access to Justice Project Offices in Addis Ababa, Child Justice Offices of the Federal Supreme Court, EWLA (Ethiopian Women Lawyers' Association) Office and, quite recently, at its Danish Government funded legal aid centers in order to enable students to handle client's cases.

An important issue that arises at this juncture relates to the reason for the non-establishment of legal clinics. This research reveals two factors. First, law schools themselves do not have the techniques of effectively managing and running legal clinics. This is not surprising because clinical courses are introduced in the LL.B curriculum quite recently. Lack of commitment of law schools and clinical teachers to undertake the rigorous assessment and supervision tasks has partly contributed to the inclination of law schools to use the delivery methods of other conventional courses in clinical courses. If clinical

${ }^{88}$ Ibid. See also arts. 7-8 of Manual on Domestic Violence Legal Clinic.

${ }^{89}$ The list of equipment and the amount distributed to each law school include: one telephone apparatus, one video camera, one computer along its table, one printer, three student dresses, one file drawer, one photocopy machine, three tonners, papers, notebooks, pens, staplers, punchers, box files, staples, paper clips, CDs, fax machine, TV sets, DVD players, broad band internet connection equipments (including internet cables, sockets, stabilizers, electric lines, other related appliances) and UPS. 
courses are to be delivered like other ordinary courses, there is no pressing need on the part of law schools to establish legal clinics. The second factor is the reluctance of universities to cover the cost for the establishment and operation of legal clinics.

\subsection{Delivery of clinical courses and student assessment}

The mode of delivery and assessment of clinical courses is different from other conventional law courses. Clinical courses combine regular classroom instruction with specially tailored exercises, simulations designed to instil the basics of good legal practice, and student observations of court proceedings. They also involve student exposure to delivery of actual legal services to clients, such as engagement in legal literacy campaigns, representation, writing of pleadings and legal counselling. ${ }^{90}$ The classroom component of clinical courses should be limited only to give students information about the nature of clinical courses and the subject matter of a specific clinical course. As a reflection of the practical nature of clinical courses, the ratio of classroom learning (including simulation) to practice is set to be $30 \%$ to $70 \%{ }^{91}$

From practical point of view, law schools can be categorized into three depending on how they are delivering clinical courses. In most law schools including Bahir Dar University, Adama Science and Technology University, University of Gondar and Jimma University, clinical courses are delivered like other conventional courses. The general trend in these law schools is to give orientation to students about the clinical course in question and then give assignment(s) which students are required to submit at the end of the semester. These law schools require students to observe court proceedings and submit reports; or require students to undertake simulation exercises. This practice does not conform with the purpose of clinical courses and does not fulfil the objective of the legal education and training reform.

The second experience relates to Addis Ababa University School of Law and Haramaya University School of Law, whereby all students of clinical courses are placed in legal aid centers after a brief classroom course introduction. Once students are sent to legal aid center, they have limited contact with their supervising instructors. The students, during their stay at legal aid centers, are supervised by paralegals employed to provide legal aid in the legal aid centers. The problem with this approach is that clinical professors do not have the chance to closely follow up their students to ensure that students are making improvements in acquiring the necessary lawyering skills and serving the clients professionally.

\footnotetext{
${ }^{90}$ Manual on Domestic Violence Legal Clinic, art. 1.

${ }^{91}$ Id., art. 15.
} 
The experience of Mekelle University School of Law can be taken as the third category. Students of clinical courses first receive some theoretical background before they are sent to the practice. After introductory class sessions, students are assigned to work in the Human Rights Center or Legal Aid Center. In the Centers, students have the opportunity either to engage in legal literacy or provide various legal services short of representation. An important experience of Mekelle University that should be emulated by other law schools is the practice of assigning the coordinator of the Human Rights Center and the Legal Aid Center to handle clinical courses. This arrangement creates conducive environment for the coordinators to closely supervise the daily activities of students.

Clinical courses are mainly meant to enrich students with practical legal skills and at the same time enable students to assume responsibility, serve the community and develop the self-confidence needed to practice effectively in a competitive, fast-paced field. ${ }^{92}$ With this end in view, assessment of clinical courses should be continuous, multidimensional and supported by extensive and immediate feedback to students. Student assessment in general should be crafted in such a way that it measures: (a) student compliance with professional standards of practicing lawyers; (b) efforts of students to discharge their educational responsibilities in terms of attendance and participation in classroom discussions and team meetings, (c) the level of learning from readings, simulations, and actual experiences, and (d) the level of mastery of lawyering skills, such as interviewing, counseling, legal research and analysis, writing/drafting and oral/legal advocacy. ${ }^{93}$

No law school in Ethiopia has fully applied these parameters of student assessment. Assessment for clinical courses is generally made based on class attendance and participation, exam, case analysis, report and presentation. The assessment has little components, lacks continuity, is not designed to evaluate students' adherence to professional standards of lawyers and is not supported by detailed and immediate feedback.

As mentioned above, students of clinical courses are required to engage in actual performance of lawyering activities in the context of rendering services to the benefit of clients. With regard to mode of supervision, the best approach is to ensure that supervision strikes a balance, to the extent possible, between the quality of legal service to be rendered to clients, on the one hand, and the freedom to be given to students in performing clinic related tasks. For such

\footnotetext{
92 Id., art. 2.

${ }^{93}$ For details, see article 5 of the Domestic Violence Legal Clinic.
} 
balancing exercise to be effective, the work of students needs to be transparent. $^{94}$

To ensure that clients are served properly while students adequately acquire the necessary lawyering skills, students should be closely supervised, supported and extensive feedback should be given. There are two important issues in relation to student supervision, i.e., the competence of supervisors and the approach thereof. Regarding competence of supervisors, scholars suggest that clinical teachers (supervisors) should possess two characteristics. One is that they should have a sufficient understanding and practice of educational theory to be able to design and implement experiences for students which will maximize their opportunities for deep learning. The second is that they should have the experience of practice which is necessary for them to act as effective supervisors of their students' attempts to advise and represent their clients. ${ }^{95}$

In practice, the selection of professors of clinical courses who primarily supervise students' engagement in clinical programs is arbitrary in most law schools. The selection process does not take into account the fact that the instructors are well versed with the theoretical and practical aspect of the law. What is surprising is that there are law schools who assign other instructors while there are instructors who have taken training on the management of legal clinics. In some law schools, clinical instructors are assigned taking into account the exposure of the person to legal practice. In Mekelle University School of Law, coordinators of the Human Rights Center and Legal Aid Center are ipso facto instructors of clinical courses.

With respect to mode of supervision, with little variations, all law schools did not apply serious supervision mechanisms for students of clinical courses. In the worst scenario, instructors of clinical courses abandon their students after giving assignments to be graded at the end of the semester in the form of presentation or written submission. There are also good practices whereby instructors attempt to continuously coach and support their students.

Clinical courses are not delivered, assessed and supervised as required under the curriculum and the manuals on legal clinics. There are a number of factors that contribute to this problem. Law schools consider large class size as the major reason for gaps in the implementation of clinical programs. Clinical courses are highly student-centered and require close supervision of students. Thus, they cannot be effectively managed in large class size. That is why the manuals on legal clinics stipulate a class size of twenty to thirty students. ${ }^{96}$

\footnotetext{
${ }^{94}$ Mizanie Abate Tadesse, supra note 6, p.42.

95 N. Duncan (2005), 'Ethical Practice and Clinical Legal Education', 7 International Journal of Clinical Legal Education 18.

${ }^{96}$ Article 16 of the Manual on Domestic Violence Legal Clinic.
} 
In many law schools, such as Bahir Dar University, Adama Science and Technology University, (whose Law School has been transferred to Arsi University since the 2014/15 academic year), Haramaya University, University of Gondar and Dire Dawa University, the class size for clinical courses is like other ordinary courses -extending up to seventy students. This has seriously hampered the delivery of clinical courses and student assessment and supervision. Other factors contributing to the problem include lack of focus and commitment of law schools and instructors of clinical courses, attitudinal problems of students and instructors towards clinical courses, transportation problems, students' preoccupation with the preparation for exit exam, and lack of expertise of instructors in clinical courses.

\subsection{Financial sources of legal clinics}

Conducting clinical courses as per curricular requirements requires a lot of resources. ${ }^{97}$ In light of the dual purpose of legal clinics -namely, teaching law students the practical aspects of the law and serving the community by rendering various legal services to the needy,- it naturally follows that universities should own them and fund their operations. At the Mekelle workshop (which was organized, inter alia, to set guidelines for the preparation of Manuals for clinical courses), it was agreed that the clinics shall be funded primarily from budgets drawn by law schools in the same manner as medical schools. ${ }^{98}$

As we have seen in the previous sections, not a single law school in the country has legal clinics per se. The optimal attempt of some law schools while teaching clinical courses is to use legal aid centers as legal clinics so that students can practice law short of representation. The pioneering ones in this regard are Mekelle University school of Law and Addis Ababa University School of Law. An issue arises whether these two schools which have made attempts to conduct clinical courses in legal aid centers have made adequate preparation to equip the centers so that they can enable them to conduct clinical courses.

In Mekelle University Law School, the budget the University allocates to the centers has neither been adequate to equip such centers as per the curricular requirements, nor has it been timely disbursed. Accordingly, the School has been soliciting funds from other sources to complement the government budget.

The case of Addis Ababa University School of Law is different. Until 2015, the School neither had legal aid nor clinical centers. It rather used the legal aid

\footnotetext{
${ }^{97}$ Id., arts. 7-8.

98 The Mekelle Workshop was held on 24 February 2008 at Milano Hotel. The participants were deans of law schools, members of the then Curriculum Implementation Committee, directors of legal aid centers and other stakeholders. The guidelines that were prepared in this workshop are incorporated in the manuals of the clinical courses.
} 
centers established by the Center for Human Rights to teach clinical courses. As of mid-February 2015, however, the Law School started to implement a twoyear Clinical Legal Education Public Interest Project financed by the Kingdom of Denmark through Royal Danish Embassy in Addis Ababa. ${ }^{99}$ The Project enabled the School to open and operate four legal aid centers in Addis Ababa although many of these centers are currently closed upon the end of the Project Period. ${ }^{100}$ Addis Ababa University has not so far allocated its own budget for legal aid centers.

\subsection{The types of services provided by students in legal clinics}

As pointed out earlier, legal clinics are non-existent in Ethiopia although clinical courses have been given in various law schools since 2010. According to the data gathered from our informants -particularly fifth law students and clinical course instructors- the clinical courses in many of the law schools have not been given as envisioned by the curriculum and the manual of clinical program. Owing to the absence of legal clinics, the mode of delivery of clinical courses in many of the law schools has sidestepped the service component of the said courses. In that case, it is hard to think of the types of services rendered by students to the community in the course of taking clinical courses. Instructors often conduct two or three classes on the theoretical background of the course and then send students to courts or other relevant institutions for observation or completion of a certain assignment. The course ends upon students' submission of a report. Our data shows that clinical courses in most law schools have failed to meet one of their core objectives, i.e. provision of legal services.

However, a few law schools have attempted to meet both the training component and the service component of clinical courses by using their legal aid centers. In this regard, as seen above, the move of Mekelle University Law School should be appreciated. Clinical courses have been offered to students under the supervision of Legal Aid Center and Human Rights Center. The Law School has used these two Centers as legal clinics to offer clinical courses. This being so, students have provided a range of legal aid services to the beneficiaries such as legal advice, drawing up of pleadings and petitions, conciliation, legal literacy. Moreover, to some extent, there have been efforts to use legal aid centers for clinical courses in the law schools of Addis Ababa University and Haramaya University.

In connection with the services toward access to justice through legal clinics, there is the need to device an arrangement for the provision of the services by

\footnotetext{
99 Project Document Regarding Addis Ababa University Clinical Legal Education Public Interest Project, December 2014.

${ }^{100}$ Interview with Yonas Birmeta, Head, School of Law, Interviewed on August 7, 2017.
} 
students without an advocacy license. ${ }^{101}$ The provision of legal services can be justified by the mandate of universities to provide community service, and it can be argued that legal clinics that involve teaching and training can be treated as exception to the requirement of advocacy license for the provision of legal services. ${ }^{102}$ Yet the attempt of students to represent indigent clients may be challenged by courts. The federal government and regions are thus expected to consider the possibility of enacting legislation which will authorize students (providing legal aid) to represent clients without an advocacy license.

\subsection{Student code of conduct}

A Model Code of Conduct was prepared under the auspices of JLSRI (Justice and Legal System Research Institute) to be used as a model in the issuance of Code of Conduct by law schools to regulate student conduct in the course of clinical programs. According to this Code of Conduct, students are required to assume different duties and responsibilities such as regular attendance, punctuality, respect for the rights of others, confidentiality, etc. The breach of this Code of Conduct entails different forms of penalty ranging from deduction of marks in the legal clinic course to academic dismissal.

As the delivery of clinical courses in most law schools disregards the service component, breach of duties in rendering services may not occur. Misconduct of students may, however, increase when students are hosted at the legal aid centers to pursue clinical courses. Under this setting, the Code of Conduct can

${ }^{101}$ The manuals on legal clinics stipulate that students, in principle, may represent clients before lowest level of the courts. However, if the case (they are handling) proceeds to a higher level of court, they should not be prevented to handle that case. If a case they are assigned to handle is not complicated, the supervisor may decide that the students handle cases that are at a higher level of court. See, for example, article 12 of the Manual of Domestic Violence Legal Clinic.

${ }^{102}$ An individual should hold license to provide such kinds of advocacy services in Ethiopia. For license requirement, see article 3(1) of Federal Courts Advocates Licensing and Registration Proclamation, Proclamation No. 199/2000, Federal Negarit Gazeta, $6^{\text {th }}$ Year No.27. Similarly, license is a requirement to render advocacy services in regions (states) under regional laws. Almost all students do not have diploma or degree in law and experience to apply for license. Under article 8 the Federal Courts Advocates Licensing and Registration Proclamation, it is only an Ethiopian who, inter alia, has a diploma in law from a legally recognized educational institution, knows the basic laws of Ethiopia and has a minimum of five years relevant experience; or has a degree in law, knows the basic laws of Ethiopia and has a minimum of two years relevant experience, shall be issued with federal first instance court advocacy license. As indicated under article 9 of the same Proclamation, it is only an Ethiopian who, inter alia, has a degree in law from a legally recognized educational institution, knows the basic laws of Ethiopia and has a minimum of five years relevant experience, shall be issued with advocacy license of Federal Courts of all levels. 
be applied to govern student behaviour during clinical courses. However, none of the law schools, which have used legal aid centers as legal clinics, has prepared a code of conduct to govern students involved in the provision of legal services. In the absence of code of conduct, law schools that use legal aid centers as legal clinics tend to use the Model Code of Conduct of clinical courses, students code of conduct, other relevant rules and regulations of their respective school or University if misconduct occurs. Our data shows that there is no reported misconduct of students during service delivery at the legal aid centers.

\subsection{Client eligibility criteria}

Developing eligibility criteria to identify the needy, the poor and marginalized section of the society enables law schools to deliver the services only to those who would not otherwise get it. ${ }^{103}$ As is evident from the experience of the three law schools that attempted to use legal aid centers as legal clinics -AAU, MU and Haramaya University- there is no well-developed beneficiary selection criteria. In most cases, subjective criteria are used to determine indigence. Information from client interviews, personal appearance and level of literacy are usually used as criteria. Women, children, persons with disabilities and elders are usually not required to adduce such evidence. The same is true regarding persons who only require counselling.

For those who require representation, however, the practice of these universities shows that support letter evidencing indigence is usually required from social courts and sometimes from the police. Referrals from association of elders, women, youth and judges are also accepted. However, students do not represent clients in the course of taking clinical courses and they do not require evidence of indigence for legal advice. Thus, persons who are not indigent also come to the centers to get such services while they have lawyers, sometimes to, inter alia, cross check what their lawyers have told them. ${ }^{104}$

\subsection{Quality assurance mechanisms}

Ensuring the quality of services delivered by clinical students is necessary for customer satisfaction and the viability of the centers. This requires mechanisms that can improve the quality of services delivered, such as: (a) proper priortraining on various sets of skills by well-trained professionals, (b) on-job observation, (c) closer supervision and follow-up, (d) discussion of cases in a team, panel/group, (e) consulting experienced persons (paralegals, center managers, course instructors, etc) and (f) referring to literature by giving an appointment to a client.

\footnotetext{
103 This would also prevent conflict of interest with practicing lawyers.

${ }^{104}$ AAU legal aid centers have encountered such problems.
} 
Mekelle University Law School has relatively better experience in this regard. Since the Legal aid Center and Human Rights Center coordinators are responsible for teaching clinical courses, they have the opportunity for closer supervision of students hosted in the centers. They also have the practice of submitting complicated cases to a panel of lawyers (instructors) in order to resolve complex issues. In general, although there are some good practices, the quality assurance mechanisms employed in Ethiopian law schools is inadequate to ensure the quality of services. The way forward envisages the need to address these gaps in all law schools.

\section{Prospects of Consolidating Legal Clinics in Ethiopia}

Our discussion above on the status of operation of legal clinics in Ethiopia demonstrates that the establishment of legal clinics in particular and the implementation of clinical programs in general are fraught with many challenges. Even though there are challenges for the functioning of the clinics, there are also the following opportunities for Ethiopian law schools.

\subsection{The possibility of using legal aid centers as legal clinics}

The majority of law schools in Ethiopia have legal aid centers in order to meet one of the objectives of their respective University i.e. rendering community services. However, the law schools have not created legal clinics for clinical courses. The experience of Mekelle University Law School i.e. using legal aid centers as legal clinics for clinical courses is a lesson that can be used in other law schools.

The use of legal aid centers to host students of clinical courses avoids unnecessary institutional duplications. Law schools can use their legal aid centers for clinical courses without the need to create legal clinics. This minimizes the resource constraints of law schools. Moreover, legal aid centers are relatively well-organized with good experience of legal services provision. Many legal aid centers of law schools are integrated into and financed by their University. The use of legal aid centers as legal clinics allows law schools to use the institutional set up, resources and experience of legal aid centers for clinical courses.

\subsection{Class size due to the 70:30 \% public universities' intake strategy}

In March 2008, the FDRE Ministry of Education has adopted a strategy titled "Annual Intake and Enrolment Growths and Professional and Program Mix of Ethiopian Public Higher Education: Strategy and Conversion Plan, 20012005.” This strategy requires public universities to annually enrol new students on basis of placement of 70 percent into the Engineering and Technology stream and 30 percent into the Social Sciences and Humanities streams. The reason stated for the introduction of the policy by the Ethiopian Government is related with the country's aspiration to achieve rapid economic development using science and technology as a major weapon. 
One may criticize the strategy for limiting the individual freedom of students to choose an academic field of their interest. The second criticism can be adverse impact to the Social Sciences and Humanities streams in attracting more competent and enthusiastic students. However, we argue that the adoption and the implementation of this strategy can also be taken as an opportunity to legal education in general and operation of legal clinics in particular owing to its contribution in lessening class size in law schools. In the 2006 Legal Education and Training Reform Document, large class size has been stated as one of the problems that negatively affect quality of legal education and the proper delivery of clinical courses.

In the past, it was not uncommon for law schools to receive up to 200 new students per year. This trend has changed over the past few years as a result of the application 70:30\% intake strategy. Law schools need to take advantage of this relatively small class size. Given that clinical courses entertain a class size of 20-30 students, the reduction of the number of students that are admitted to law schools could be an opportunity for the better management of legal clinics. In addition to class size, however, there is the need to take note of the extent to which legal education is among the first choice of students who have relatively high grades in university entrance national examinations. This factor can, inter alia, be influenced by the quality, relevance and standards in legal education, and the magnitude of merit-based employment opportunities upon graduation.

\subsection{Increasing enthusiasm of universities to fund legal education}

In addition to clinical courses, the 2006 LL.B national curriculum has incorporated externship and exit exam. During the initial years of their implementation, however, these courses had caused controversy and ambiguities. The modality of course delivery and assessment, the outcome of failing in these courses and the source of budget were some of the major problems. Because laws schools were not prepared to cover the huge budget need to run the courses, this responsibility was shouldered by Justice and Legal System Research Institute (JLSRI) and later by the Education Strategic Center (ESC) until the 2007 EC (2014/15) budget year. Budgetary constraints and delayed release of budget for the administration of these courses have at times resulted in the postponement of exit exam dates and reducing the number of dates required for externship attachment.

In 2006 E.C. (2013/14 Academic Year), the Ministry of Education has issued a circular requiring all universities to allocate adequate budget for the administration of exit exam and externship proportional to the number of their fifth year students. Accordingly, since 2015, universities are allocating budget to exit exam and externship and they cover the cost to administer the courses. The same can be done with regard to legal clinics. 


\subsection{Increased attention of universities to community services}

Apart from undertaking problem-solving studies and providing quality education and training, universities should render services to the community. ${ }^{105}$ However, community service and research missions of Ethiopian universities were given little attention compared to education and training. In the specific context of Ethiopian law schools which could also apply to other disciplines, the provision of community service has been low mainly due to the culture of giving secondary significance to community service, and because of structural, procedural, resource-related, competence and networking problems. ${ }^{106}$

There are current trends of improvement in this regard. Universities are taking measures that enable them to discharge their community service mandate. The community service activities of all Ethiopian universities are coordinated by top-level office holders in universities. More importantly, some universities including Bahir Dar University have set up a remunerated position of community service at law school level. Although there is much to be done, universities have increased the annual budget for community service. ${ }^{107}$ These measures reflect the commitment of universities to enhance the provision of community services. As legal clinics are important avenues toward discharging community services, they can benefit from the attention that is duly given to community services.

\subsection{Opportunities for external funding}

One of the challenges universities face to establish and run well equipped legal clinics is lack of funding. Given the overall resource limitations in the country, institutionalizing legal clinics within the structure of the universities will not entirely solve funding limitations. Looking for external funding to complement budgetary allocation by universities is thus essential.

The Civil Society Organizations (CSOs) Proclamation does not prohibit law schools from securing external funding. The Proclamation allows activities related with human rights and access to justice only to Ethiopian Civil Society Organizations, or CSOs which have only Ethiopian nationals who reside in Ethiopia as members, and collect at least $90 \%$ of their income locally. ${ }^{108}$ Other CSOs that collect more than $10 \%$ of their income from foreign sources, or which are classified as Ethiopian Resident or Foreign CSOs cannot engage in these activities. ${ }^{109}$

\footnotetext{
${ }^{105}$ Higher Education Proclamation, Proclamation No. 650/2009, Federal Negarit Gazeta, 15th Year No.64, Art. 4(4).

${ }^{106}$ Legal Education and Training Reform Document, supra note 67, Sec. 2.4.2.

${ }^{107}$ For example, Bahir Dar University endorsed 9, 983,000.00 Birr for the 2007 budget year. The University has increased this budget to 23 million for 2009 budget year.

${ }^{108}$ Charities and Societies Proclamation No. 621/2009, art. 2 (2-4).

${ }^{109}$ Id., arts. 2(5), 14 (2 \& 5).
} 
Owing to the funding trap, most CSOs have ceased their operations or are registered as Ethiopian Resident or Foreign CSOs, and could not continue their human rights and access to justice activities. ${ }^{110}$ Ethiopian CSOs on the other hand, are not able to expand their human rights and access to justice activities due to funding limitations. As a result, external funders who want partners to work in these areas are either forced to withdraw their funds or change their orientation thereby leaving wide gaps in such projects. ${ }^{111}$

However, these funding limitations do not apply to university-based legal clinics. Thus, they can access the pool of foreign funders to establish legal clinics and expand their services to the needy, poor and marginalized sections of the society. This can enhance their pursuits to fulfil their mandate of community service through expanded and high quality legal aid.

\section{Conclusion}

Both the 2006 LL.B curriculum and the 2013 National Modularized LL.B Curriculum entrust clinical courses with two objectives: training students on the practical application the law, and rendering legal services to the indigent and the vulnerable. Accordingly, law schools in Ethiopia are offering clinical courses. The analysis in the preceding sections shows the status and operation of clinical programs of Ethiopian law schools in terms of establishment of legal clinics, modes of delivery and assessment, financial sources, types of services, students' code of conduct, and client eligibility criteria.

Although the proper delivery and management of clinical courses presupposes the establishment of legal clinics with the necessary facilities, none of the law schools has established a legal clinic per se. Lack of expertise on the part of law schools to effectively manage and run clinical programs, lack of commitment of law schools, and reluctance of universities to cover the necessary cost for the establishment and operation of legal clinics have been identified as the reasons for the non-existence of legal clinics. Yet, there is the commendable practice of using legal aid centers to host students of clinical courses in certain universities. In terms of finance, the legal aid in many law schools' centers largely depends on external funds although a few are, to some extent, funded by their respective universities.

${ }^{110}$ Aalen, Lovise and Tronvoll, Kjetil (2009), 'The End of Democracy? Curtailing Political and Civil Rights in Ethiopia”, Review of African Political Economy, Vol. 36, no.2 , pp. 13-19.

${ }^{111}$ Carl Gershman, and Michael Allen (2006), "New Threats to Freedom: The Assault on Democracy Assistance”, Journal of Democracy, Vol. 17, No. 2, $<$ http://muse.jhu.edu/journals/journal_of_democracy/v017/17.2gershman.pdf>. See also Hailegebriel, Debebe (2010), Sub-Saharan Africa Country Reports: Ethiopia, International Journal of Not-for-Profit Law, vol. 12, no.2. 
Regarding delivery, clinical courses are delivered similar to other conventional courses in most law schools. The experience of these law schools is incompatible with the purpose of clinical courses and undermines the objective of the legal education and training reform. In terms of student assessment, Ethiopian law schools have not complied with continuous, multidimensional and feedback-supported assessment standards for clinical programs. The assessment has little components, lacks continuity, is not designed to evaluate students' adherence to professional standards of lawyers and is not supported by detail and immediate feedback. The selection of professors of clinical courses who primarily supervise students' engagement in clinical programs is generally arbitrary in most law schools. With respect to mode of supervision, with little variation, all law schools did not apply serious supervision mechanisms for students of clinical courses.

Legal clinics have to provide legal aid services to the vulnerable section of the society who cannot otherwise have access to justice. To this end, law schools should have a well developed beneficiary selection criteria. This is lacking in Ethiopian law schools, and in most cases, subjective criteria are used to determine indigence. Regarding regulation of student misconduct, each law school is expected to develop a comprehensive code of conduct specifically designed to clinical programs to regulate the behaviour of students in the course of service delivery. Many law schools tend to use the students' code of conduct, other relevant rules and regulations of their respective school or University if misconduct occurs.

Although legal clinics have not been established in Ethiopian law schools and in spite of the challenges in administering clinical courses, law schools can make use of the opportunities that are available to run clinical programs properly. The opportunities include the use of legal aid centers to students of clinical course with the necessary improvements, reduced class size in law schools as a result of 70:30 intake strategy, the propensity of universities to own and fund legal aid services, the focus of universities on community services, and the non-applicability of the CSO Proclamation on the funding sources of law school clinical programs.

In view of the above mentioned gaps, limitations and opportunities, it is submitted that law schools should give adequate emphasis to clinical courses, use the already existing legal aid centers as legal clinics, and strengthen their cooperation with stakeholders. Universities should indeed own and finance legal clinics so that clinical programs can meaningfully contribute to the realization of access to justice for the poor and the vulnerable. 